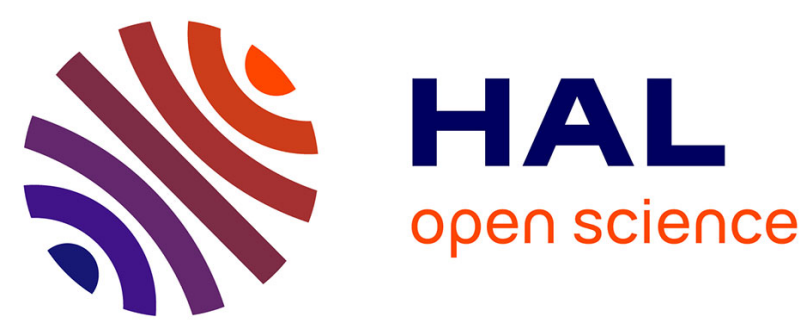

\title{
Do street traders have the 'right to the city'? The politics of street trader organisations in inner city Johannesburg, post-Operation Clean Sweep
}

Claire Bénit-Gbaffou

\section{- To cite this version:}

Claire Bénit-Gbaffou. Do street traders have the 'right to the city'? The politics of street trader organisations in inner city Johannesburg, post-Operation Clean Sweep. Third World Quarterly, 2016, 37 (6), pp.1102-1129. 10.1080/01436597.2016.1141660 . halshs-02782445

\section{HAL Id: halshs-02782445}

https://shs.hal.science/halshs-02782445

Submitted on 4 Jun 2020

HAL is a multi-disciplinary open access archive for the deposit and dissemination of scientific research documents, whether they are published or not. The documents may come from teaching and research institutions in France or abroad, or from public or private research centers.
L'archive ouverte pluridisciplinaire HAL, est destinée au dépôt et à la diffusion de documents scientifiques de niveau recherche, publiés ou non, émanant des établissements d'enseignement et de recherche français ou étrangers, des laboratoires publics ou privés. 


\title{
Do street traders have the "right to the City"? The politics of street trader organizations in inner city Johannesburg, post Operation Clean Sweep
}

\author{
Revised version of a paper to be published in Third World Quarterly, 37(6), 2016
}

\author{
Claire Benit-Gbaffou \\ Associate Professor, \\ CUBES \& School of Architecture and Planning, Wits University, \\ Private Bag 3, WITS 2050, Johannesburg \\ Tel: +27.11.717.77.18 / Fax:+27.86.553.52.32 / Cell:+27.78.613.60.24 \\ Email: claire.benit@wits.ac.za
}

\begin{abstract}
Street trader organizations are paradoxical objects of study. Their claims resist being analyzed through the "right to the City" lens, so contested are rights to inner city spaces between multiple users, not all of them in dominant socio-economic positions; and so ambiguous is the figure of the street trader, oppressed but also appropriating public space for profit; increasingly claiming, in neoliberalising cities, an entrepreneurial identity. In the aftermath of the 2013 'Operation Clean Sweep' (where the City of Johannesburg unsuccessfully attempted to evict street traders from its $(B D)$, the paper unpacks the politics of street trader organizations: how they organize their constituencies, frame their claims, forge unlikely alliances and enter in divisive conflicts, in engagements with a divisive municipality.
\end{abstract}

\section{Key words}

Street trading, organisations, politics, Johannesburg

\section{Word count}

Main text, without abstract, references, footnote, etc.: 10128. All included: 13022.

\section{Acknowledgement}

A version of this paper was presented at the ECAS conference in Paris, July 2015. The paper is based on the author's own fieldwork and activist engagement with trader leaders, to whom she wishes to express her gratitude. It is also based on joint workshops, run with colleagues in the Center for Urbanism and the Built Environment (CUBES) throughout 2014 and 2015; and a class project with students from Planning and Politics at Wits University (whose work is referenced in the text), that constituted stimulating spaces of research and debate. Views and interpretations are my own.

\section{Short Bio}

Claire Benit-Gbaffou, PhD Geography, is an Associate Professor at the School of Architecture and Planning, Wits University. She is a researcher in the Center for Urbanism and the Built Environment Studies (CUBES), at Wits, and an associate researcher in LAVUE (Mosaiques), a research entity in the University of Paris Ouest Nanterre La Defense. She has published extensively on urban politics, community participation, informal leadership, and political clientelism. 


\section{Introduction}

It is about two years after Operation Clean Sweep. In October 2013, the City of Johannesburg brutally evicted all traders from the streets of inner city Johannesburg. Most of these traders did not belong to street trading organisations, did not have an easy recourse to a language of "rights" as most of them were trading "illegally" in the inner city. Most of them were not organised neither making collective claims, but were used to adopting a politics of invisibility, of every day arrangements and constant mobility ${ }^{1}$.

Yet, if it was not for street trading organisations in Johannesburg, Operation Clean Sweep could have succeeded, if not in definitely chasing away traders from inner city streets, at least in temporarily interrupting livelihoods for a longer period of time, and in legitimising the fact that street traders can and should be treated as human waste. Even if divided, Johannesburg street trader organisations have opposed and successfully delegitimized, through strong Constitutional Court statements, such a brutal, arbitrary and contemptuous way for the state to solve urban issues. The City will have to find other ways, legal ways - and in the process, the content of its restrictive policy might be affected. In fact, it already has, as the number of legal street traders envisaged by the City has shifted from 1500 in November $2013^{2}$ to 3700 in August $2014^{3}$, to a future $7500^{4}$.

Street trader organizations, in spite of their shortcomings, persist in the political landscape of developing cities. Their leaders might change affiliation but continue struggling for a cause, build knowledge and networks, identity and resources, seize opportunities and respond to constraints. They persist because there is a structural oppression of street trading, all across the world ${ }^{5}$. Street trading is generally, for a variety of reasons, expelled or severely restricted from centers in Cities of the South ${ }^{6}$. Episodes of inclusion and accommodation of street trading in inner cities exist, but are often short-lived, generally followed by political backlashes putting emphasis on street trading repression and restriction ${ }^{7}$. Except where street traders have been extremely organised, using their collective vote to render politicians accountable ${ }^{8}$, or when local authorities are faced with an imperative necessity to foster social cohesion and reconciliation (as it has been the case in Durban ${ }^{9}$, in the midst of the 1990s local political violence; or in postwar Monrovia ${ }^{10}$ ), local authorities in metropolitan areas ${ }^{11}$ across the world have generally focused on restricting rather than embracing and regulating street traders' presence in inner cities.. It is not the purpose of this paper to explore the reasons for the dominance of restrictive approaches to street trading ${ }^{12}$ - to be found between the reproduction of colonial orders, the rising aspirations to global city status ${ }^{13}$, the lack of planning and design alternative imaginations ${ }^{14}$, vested interests in the status quo, and the reality of municipal challenges in managing highly fluid, and locally embedded, practices ${ }^{15}$, to name a few. Suffice for the purpose of this paper, is to say that across global metropolitan areas, street traders politics have been framed by fluctuating but generally antagonistic relationships with local authorities, and forms of resistance to approaches continuously marked by a degree of restriction and repression.

Whist the overt fight against restrictive municipal policies and practices does not fully account for street trader politics, the constant threat of eviction, restriction and abuse forms the bulk of street trader organizations' raison d'être. As such, street trading organisations are worthy of being studied in cities of the South.

This paper analyses the contemporary political landscape of street trader organisations operating in inner city Johannesburg. It interrogates the nature of street trading organization politics, using 
Operation Clean Sweep as an entry point into their fragmented and competitive nature. It locates this interrogation in a theoretical exploration of frameworks and concepts generally used to analyse street trading organization politics - between fragmented, fluid and postmodernist agency (a politics of invisibility, clientelism and ad hoc arrangements); and the notion that the traders exert their "right to the city", even though they hardly fit a lefebvrian interest for non- or anti-capitalist imagination of the city. Bringing attention to the dual nature of street traders contemporary political identity (as oppressed and marginalised groups, but also as individual entrepreneurs), it unpacks street traders organizational choices, arguing that in spite of organizations' informal nature, these choices (of structure, of leadership, of positions and practices) matter and highlight core issues of democracy, representativeness and political efficiency.

The paper is based on several sources and methodologies. The author has been engaging in actionresearch, building strong networks with street trader organizations since 2010. On this basis, these organisations approached CUBES ${ }^{16}$ in the aftermath of Operation Clean Sweep, to request support through research in their engagement with the City. The author coordinated, for the whole of 2014, monthly workshops with seven street trading organizations operating in the inner city of Johannesburg. She also facilitated a Wits University class research project on trader organization politics, based on interviews with leadership, mapping and archival work ${ }^{17}$. This paper is based both on this collective report and the author's own extensive and ongoing engagement with street trader organizations. The authors' position, as academic-activist in this field, has given her a unique opportunity to engage over a long period of time with street trader organisations: to observe, discuss and debate, sometimes advise on their political practices on the one hand; and to learn on informal politics in the city on the other. It has furthermore pushed the author to constantly confront theories and practices, to continuously search for ways of embedding broad (academic and political) principles into practical solutions, that could be responding to street traders but also municipal authorities' policy and practical needs. This position has also exposed the author to some of the harsh realities of the street trader organisations' external and internal politics, including in their less progressive components (political competition, struggle for positions, opaque financial deals, xenophobic temptations, inter alia), that the author's position gives her the opportunity to engage upon, with traders organizations, in incremental ways; but also to contextualize in the broader academic literature on informal politics and governance. This paper is therefore based on unique insights gained in actual practice and long-term engagement, and premised on an overall position of sympathy for street trading organisations' struggles, that is not blind to their shortcomings nor romanticizing their politics: somehow a biased position, but not unconsciously nor inconsiderately so.

The paper starts with a preamble, locating it in broader academic debates on social movements, street trader politics, and urban governance, and debating relevant theoretical framework to analyse traders' mobilisation for a place in the city. The paper then analyses Operation Clean Sweep as a revelator of traders organisations' fragmented politics, that it takes as the basis to depict and frame a political landscape of traders organisations in inner city of Johannesburg - arguing each one is crafting a particular, if overlapping, political niche for itself. The last section identifies issues of representation as central to their claims for a "right to the city", and yet, due to their intricate and competitive spatial politics, also the main shortcoming in their demands for degrees of selfmanagement. 


\section{Preamble - Research, informal politics and street trader organisations}

Street trading organisations are often looked down upon. First by political commentators, who see street trader leaders as "opportunistic"18, call their protests "popcorn protests", constantly question their legitimacy based on their multiplicity, narrow interests and chronic division. The State, but also various types of NGOs (including legal ones), insist on engaging with a united body of legitimate trader representatives - and are quick to discredit their organisations as lacking continuity, legitimacy, representativeness, and strategic vision. Their prerequisite for engagement is admittedly based on practical reasons. It is also a form of political hypocrisy, as the state is far from being innocent of traders divisions: it is easy to claim that divisions are what prevents state's own meaningful engagement with the sector, when they are also the state's making.

Academic analysts to some extent share this cautious take on street trader organisations, and have not often taken them as the direct object of their analysis - for different reasons however. Even if street trader politics are now at the center of scholarly attention ${ }^{19}$, after having been marginalised by a predominant focus on their economic dynamics, and by an assumption of their lack of political agency, analyses seldom focus on trader organisations as the object of their study. Street trading organisations are indeed seen as representing the tip of the iceberg. Focusing mostly on legal traders and protecting those traders' (legitimate but narrow) interests (often with limited success), while ignoring or not managing to attract a majority of traders who adopt other types of politics, such organizations are often considered irrelevant for understanding the reality of street trading politics. Their study is often discarded as ill-adapted to the nature of contemporary cities of the South ${ }^{20}$. Far from being analysed through the lens of "radical contention" or "insurgent citizenship" ${ }^{21}$, street traders are often understood as a collective of atomised individuals - forming what Asef Bayat calls "uncivil society", as they assert their right to the city not by overt contention and mass mobilisation, but by the power of inertia, of the "quiet encroachement of the ordinary" ${ }^{22}$. Bayat analyse the mass of traders as only related by "passive networks", mutual visual acknowledgement and minimal street solidarity, based on the common occupation of a street and a shared alertness to police movements. Kamete warns against what he calls modernist expectations of tales of resistance ${ }^{23}$ : an overt confrontation with City policies on the basis of rights, an explicit collective claim for a place in the city. He rather investigates traders' resistance in a "post-modernist" frame, looking for arrangements, clientelistic networks, defining a politics of invisibility. These arrangements are seen as the dominant, everyday mode of governance of street trading ${ }^{24}$, only occasionally disrupted by waves of repression: the rare moments where street traders might feel the need for (ephemeral, "popping up") collective mobilisation. Informal traders everyday politics are also the focus of Wafer's work, unpacking the contentious construction of a market in central Johannesburg ${ }^{25}$. Wafer's interest lies in excavating the traders' political subjectivities, constructed in complex and fluid forms of engagement _with the state, which he argues are not primarily based on confrontation and resistance but more on the joint framing, by state and traders themselves and through state interventions and projects, of a sense of urban citizenship. This attention to traders' discourses, experiences and expectations from the state, paralleled by state officials' representation of traders, allows for a rich and nuanced understanding of the governmentality of street trading.

These approaches, crafting innovative objects of research reflecting on the everyday politics of "most of the traders" (to paraphrase Chatterjee), however directly or indirectly contribute to construct or consolidate street trader organisations as marginal, inefficient, unrepresentative and therefore 
fundamentally irrelevant. Perhaps because of their focus on the everyday and the micro-scale dimension of politics, they fail to see (or perhaps decide to ignore), structural positions and longer terms forms of overt or covert mobilisation, that arguably are embedded in these organisations' histories, discourses and practices. Whilst the "irrelevance" of street trader organisations might be the lived reality of a majority of traders (trader organisations themselves complain about the lack of loyalty of their "members", calling organisations in times of crisis but disappearing as soon as issues are solved), this understanding only tells half of the story, that a more focused attention to the politics of street trading organisations might usefully complement.

It is relatively recently that scholars have highlighted the "changing politics" of informality, and paid more attention to the collective agency of informal traders, conceptualised as "informal workers" 26 . Most studies in this vein still qualify street traders" "voice" as weak, as opposed to the other option of "exit" 27 - whilst only a minority of traders, those granted legal rights to trade in generally restrictive municipal frameworks, would play the "loyalty" card and use clientelistic networks. Chatterjee's concepts help us reconsider street trader organisations as the epitome of "political society", that he defines by the informal status of its members, making their use of a language of rights more difficult, and increasing the likelihood of their recourses to favours - possibly at a collective level, using the power of democratic vote or mass violence to leverage some collective benefit, such as a temporary tolerance, if not full recognition, from state officials ${ }^{28}$.

This paper, even if only starting to scratch the surface of street trading organisations, demonstrates that organisations do not just "pop up". Organisations have histories: they have a sustained existence and a degree of continuity even if they are often extremely personalised. Their leaders are active, working hard - yes, fighting for positions, status and money, like most political entrepreneurs ${ }^{29}$; but also sacrificing their own business to mediate, solve issues, confront, alert the media, go on the ground; or, attend meetings, read documents, prepare inputs and submissions, debate with lawyers and academics. Their battles might be invisible, as the result of their action in most cases is often limited to temporarily blocking further municipal repression. There is, in South Africa, limited evidence of their influence over policy or long-lasting change in the practices of the state (and the local state in particular) towards the sector ${ }^{30}$. But, if organisations are sometimes dormant, if leadership level of commitment and activity is uneven in time, if leaders are often changing affiliation, there are also strong elements of continuity that are overlooked -they are responses to structural inequalities and injustices in Cities of the South.

Such structural position would lead to considering street trading organizations as forms of social movement: yet, they are generally not included in this field of study, and most authors avoid using that term to analyse street trader organizations. This could be explained by their divisions, their intrinsic fragility and fluidity, and their non-representativeness of a majority of street traders: yet, this feature arguably is shared by many social movements. What makes street trader organisations challenging to assimilate fully with social movements is mostly their lack of clear -let alone radicalideological position, which can be linked, distinctively from classic social movements, to street traders' ambiguous identity: oppressed and marginalised (and fighting for a right to use central spaces in the city; for a place in the city), but also defining themselves (increasingly in a neoliberal $\mathrm{era}^{31}$ ) as emerging entrepreneurs, making profit from a form of privatization - the private appropriation of public space. 
This dual identity makes it equally complicated to study street trader organisations as informal workers unions. Some organisations use this term for themselves, and have political networks with labour unions ${ }^{32}$. Some analysts focus on the existing and potential linkages between street trader organisations and workers unions $\mathrm{s}^{33}$, and call for street trader organizations to learn from union organizational forms and skills ${ }^{34}$. But most agree this is a challenging analogy ${ }^{35}$, as street traders are self-employed entrepreneurs, openly in competition with one another in the street space, and although some of their struggles are shared (working conditions, access, legalisation and maintenance of trading space, infrastructure provision), they also have a direct interest in regulating and limiting the number of co-workers in their trading area.

This fundamental ambiguity in their identity as urban agent renders problematic the use of the lefebvrian concept of "the right to the city" to describe their struggle. Their claim to a place in the city is done in an essentially capitalist and competitive way, that puts them not only in competition with one another as traders, but also in competition with other land users (including low-income ones) in the busy, vibrant, dense and diverse spaces that are the most appropriate and conducive to their business. Their struggle might be framed in terms of use value against exchange value (fighting to alter the image of the global, Northern city and 'africanise' it); or it might be framed in terms of small, emerging, or even survivalist capitalists against more established capitalists (property developers but also informal taxi drivers and other transport operators). But it could also be framed in terms of competing use value, where degrees of street congestion might reach levels impeding low-income pedestrian uses of the street - where they would capture market value at the expense of pedestrian use value.

These theorisations, each one unsatisfactory but each uncovering one dimension of street trading organization politics, help map the terrain from which to unpack their complexity and messinessthat we will start exposing through organisations' fragmented reaction to Operation Clean Sweep. Such an operation could have been expected to be one of these highly repressive moments fostering ephemeral mobilisation and unity amongst traders, described by Bayat ${ }^{36}$ : this was not even the case.

\section{A. Operation Clean Sweep as a revelator - the fragmented politics of street trading organisations in Johannesburg}

Has Operation Clean Sweep created collective awareness that street trader organisations need to overcome their divisions? Or has it revealed, and also perhaps created or rather reinforced, crystallized, rigidified, lines of factures between them?

\section{1) A victory for the traders}

Amongst 8 street trader organizations currently operating in inner city Johannesburg, two of them, SANTRA and SAITF ${ }^{37}$, have (successfully) challenged Operation Clean Sweep in Court - on the ground that the City had acted unlawfully by chasing legal traders from the streets (as a matter of "convenience", the City argued, as sorting the "legal" from the "illegal" traders was complicated). This court decision in reality reopened the streets to all traders. But Operation Clean Sweep started by an agreement between the City, the block leaders ${ }^{38}$ and most organisations' leadership: the City was about to embark on a "clean sweep" to chase away all "illegal traders", with the support of the "legal" ones. At the meeting where this was announced, on the 30th of September 2014, block leaders were requested to help the police sort out the "legals" from the "illegals": nobody contested, everyone agreed. 


Figure 1 - No opposition from trader leaders to Clean Sweep when the Operation is announced
"On the 27 th of September 2014 , the City sent block leaders an SMS to join a meeting for the 30 th of September.
The Metro Police announced at that meeting that on the $1_{\text {st }}$ of October, the City would conduct a Clean Sweep,
as the Mayor complained that the City was unclean, congested, unsafe. They wanted to work with us block
leaders, to identify those who have smart cards, and clean sweep illegal traders. Then, we were surprised
when they started on De Villiers and King George Streets, and chased everyone, and it then snowballed, street
by street, block by block, destroying kiosks and stalls and chasing all traders without notice. Metro police
officers only said 'Mandate of the Mayor!' "
(GIDA Deputy Chair, 2014)

None of the organisations stood up against the Operation as initially presented, even those whose constituencies are partly made of unauthorised traders - sacrificed to the altar of the majority of their constituents, which (legitimately?) complain about those unmanaged traders who do not pay rent, do not clean the public space, just sit in front of them and steal their customers. When traders started to contest the "clean sweep", was when police officers, far from consulting with block leaders in their eviction drive, indiscriminately chased authorised and non-authorised traders.

This distinction was also the take of the lawyers involved in the case, and notably the Socio Economic Rights Institute (SERI), at the forefront of the battle. Understandably, it was easier to win a case on the City contradicting its own legislation and unilaterally suspending the trading licenses it had itself allocated. It did not matter that much if the list of traders presented by both SAITF and SANTRA, as those legal traders unduly evicted by the Operation, was not easy to verify and perhaps did not only represent "legal traders" - the City databases were so messy and unrepresentative that verification of the traders on the list could not really happen.

Ultimately, the Constitutional ruling went further than condemning the City for chasing away "legal traders"- it qualified the operation as an act of "humiliation and degradation" and stated the City's attitude "may well border on the cynical" 39 . Ultimately, all traders went back to trade on the streets, and the City is compelled to find legal ways to respond to its challenges in terms of managing street trading. Operation Clean Sweep, and the disruption of thousands of families' livelihoods, were halted thanks to those two street trading organisations - SAITF and SANTRA, ATO to some extent, being at the forefront of the confrontation with the City, leading the litigation. They might have fought for narrow interests ("legal traders"), out of an efficient legal strategy or out of response to their main members' immediate interests: but the victory is for all, as stated by GIDA.

"We are not an organization that reject stones [sic]. We do not engaged in politics, we are more interested in traders development as businesspeople. [... But during Operation Clean Sweep] we came together as one, because at the end of the day we are all traders, no matter what different names we have. An injury to one is an injury to all. When SAITF won the court case against Operation Clean Sweep, it was for all of us" (GIDA leader 2014).

\section{2) Leading to the court case - an impossible unity}

If SANTRA and SAITF's court victory was a victory for all, narratives of the steps leading to the court case reveal far more contrasted positions and strategies. First, the calls for united action of all traders, uttered by NGOs involved in the sector (such as ESSET, Ecumenical Services for Socio- 
ecumenical Transformation, which used to support SAITF, SANTRA and GIDA) as well as the South African federation of trade unions, COSATU (attempting to federate the sector, but playing competitive politics, in particular with SAITF), all failed in the face of fragmented initiatives, and the absence of a legitimate unifier of the sector.

Figure 2 - The inability to mobilise as a united front against OCS

"On the 22nd of October, all organizations called each for a meeting. One Voice called for a meeting, so did SANTRA, so did SAITF. We in GIDA had our meeting with ESSET on the 22nd. ESSET proposed to hook us with the South African Human Rights Commission (SAHRC), but not us as GIDA - we needed to come to them with all trader organizations. Thereafter we split up: Mike went to SAITF meeting at Bree taxi rank, I went to SANTRA meeting at the Anglican Church - One Voice was there too. Reverend Mcophela from ESSET went with me. So, I reported that we needed to create a united front and then we could approach the SAHRC. At that meeting it was resolved that ESSET would call an urgent meeting of the Chairpersons of all traders' organizations for that afternoon in order to discuss a united front.

What happened however was that on the 24th, a march was planned by a socialist organization that contested the elections, supporting traders on de Villiers [ATO]. SAITF joined their march. One Voice had their own march planned for the 25th. All separate marches. SANTRA also mentioned a sit-in at the Mayor's office. At that point it became clear each organization had its own plan of action. It became then very difficult for GIDA to bring all leaders together. We asked COSATU for help in calling all the leaders, but SAITF would not go to COSATU, and they were busy now contacting SERI. During that time our members were attending meetings with City officials as a collective with other leaders almost every day, with no resolution. As GIDA, we then took a back seat. We stopped engaging; told our block leaders to submit lists of traders' names, so that some of our members joined SAITF and SANTRA court list as 'traders affected'."

(GIDA deputy Chair, 2014)

More dramatic perhaps than this lack of unity in resistance to the Operation, what surfaced were various instrumental uses of the Operation by organizations to claim trading spaces for their own members. Traders were to be "verified" by City officials against its database, and only then allowed to return to their trading spaces (or be allocated a new one). Some organizations, such as SAITF, challenged this whole process, not without internal debate. Some embarked onto it, hoping to use the process to negotiate more trading spaces for their members. 


\section{Figure 3 - Lines of fracture}

"During Operation Clean Sweep, we got a meeting with the [City]. All organizations' leaders attended, and we decided we needed to caucus before the meeting. We got to a common position, which was, "We can't be negotiating while people are not trading. We can't verify legal traders without people being on the street". We elected two people to speak on our behalf, as we could not all speak. Then, we get into the official's meeting, and Zacharia [One Voice leader] seems to have forgotten everything! He is no longer with us, and ends up supporting the verification process. He is followed by Lulama from JOWEDET, which used to be our affiliate, but now starts departing from SAITF and speaking with its own voice.

The deal was "you are going to occupy the spaces that foreigners were occupying". JOWEDET had its eye on Kerk street linear market. We did eventually found them allocating their people there, while we were busy in court. I remember, I organized people from the court, "let us all go to Kerk street!", and we found officials and block leaders busy allocating people in the vacated trading spaces. We stopped the whole process, officials ran away.

What had happened is that the City had organized a Joint Operation Committee (JOC), with [City officials], the Metro Police, One Voice and JOWEDET. The two organizations stated that they were agreeing with the City, and wanted to work with them. The JOC was busy verifying traders, calling Home Affairs in the process, confiscating papers, organizing reallocation of trading spaces, making new smart cards.

Even in SAITF traders were divided. Some wanted to be part of JOC. SAITF' line was "we were all stopped, we will all go back". It also meant, "if we are not going back no one is going back". Some traders still wanted to go to JOC, we messed up their stock to stop them from trading, police even tried to protect them. JOC was really stopped when we won in Court. They were based in Bree Mall. We went there too and caused chaos... Officials did not know what was happening. There were lots of traders there, queuing to be verified: we shouted, "Go and trade NOW! We have WON! This is what the Court said!". That is how we stopped JOC."

(SAITF leader, 2014)

A line of fracture emerged between One Voice and Jowedet, on the one hand (cooperating with the City, opposing the court case, hoping to use the operation for their own benefit), SAITF and SANTRA, with ATO, on the other (leading litigation, refusing any form of cooperation), with other organizations sitting in between (GIDA and NUT). This difference existed before - between more cooperative- clientelistic organizations versus more antagonistic- policy and rights based ones: but then was a clear moment of publicizing these choices.

\section{3) The aftermath of Operation Clean Sweep - participating to define the new municipal approach}

Operation Clean Sweep reshaped the political landscape of street trading organisations. SAITF and SANTRA, at the forefront of successful litigation, gained visibility in the eyes of the traders, and attracted membership at the expense of One Voice, for instance. Operation Clean Sweep also changed the way both organisations work and structure themselves. With new resources - legal advisers, increased membership numbers, and block leaders joining them, former informal ways of doing were challenged. SAITF takes more of a legal edge and institutionalises its modus operandi; SANTRA envisages restructuring the linkages between leadership and the basis, beyond personal networks. 
SANTRA and SAITF also gained leverage on State officials- they are no longer treated with negligence, and the City legal adviser is now systematically invited at each of their encounters. Is this leading to increased respect and consideration in engagements between the City and the sector (or part of it)? Or is it making constructive engagement impossible because of fear and distrust now rigidified into legal battles (but was constructive engagement ever going to happen)?

Operation Clean Sweep has certainly severed the few, fraught but existing, channels of communication between the City and street trading leaders (organisations and block leaders). The Informal Trader Forum, a platform for engagement between trader leaders and the City, that was strongly criticised for its divide and rule politics, and its inability (some say intentional) to construct and follow up on strategic inputs from the sector, is now missed as at least having provided a space where trader leaders could minimally engage with the City. The monthly block leaders meetings (decried by organisations as spaces of corruption and undermining of the sector) are showing by their absence how every day practical issues cannot be resolved out of a permanent link between traders and the City. Johannesburg Property Company (JPC), now managing markets and street traders, turns a deaf ear to traders and grounded officials' concerns, and tell them to "put your concern in writing and talk to our lawyer".

This interruption of communication channels is not compensated by the discontinuous and sanitised participatory workshops organised by the Department of Economic Development (DED), since August 2014, to "promulgate and designate trading spaces in the inner city" afresh. These workshops have called for all "stakeholders" (traders and property owners alike) to make separate submissions to the City - on the basis of which DED will propose a way forward, without any of the key choices having being publicized and discussed. In CUBES attempt to organize street trader organisations' structured inputs into these processes, throughout 2014 and 2015, it was daunting to build an agreement to challenge the legal-versus-illegal trader divide. Trader organisations were for their majority reluctant to fight for a universal legalisation of existing traders: none of them made it an explicit and strong claim, beyond a few discrete leaders in their individual capacity. Few contested the number of legal spaces arbitrarily decided by the City. All agreed that traders should be free to trade and able to develop, but which traders? Many were happier to curb competition: "legalise our members but protect us from others and preserve our market through strong enforcement", "there are too many traders, it is now becoming congested". Most were worried that under a "full legalization" slogan, their claims to precedence would vanish, they would lose the legitimacy conferred by the long time they have spent in the street, building their customer basis and crafting their trading spaces. Other wanted to redefine the place of foreigners in the city, arguing their number should be limited, as scarce public resources such as trading spaces need to benefit South Africans first. Very few argued that there is space for trading in the city - and that the many streets extracted from the discussion, proclaimed non trading areas under City Improvement Districts management in particular, should be included in the debate.

Progressive politics, dreams of inclusion and liberal rights to trade in the city, even if marred with pragmatic ideas on how to define and negotiate trading spaces at a local level, are left wanting, in the face of legitimate, but individualistic and divisive business concerns. How to better understand these claims, these concerns, the tenacity of such divisions? Profiling each organization leadership, retracing their history and unpacking their organizational structure, deciphering their stated as well as practical agendas, help making better sense of these divisions. 


\section{B. A political landscape of street trader organisations in Johannesburg}

Notwithstanding the politics of informality adopted by most traders in various forms and degrees, it seemed important to have a better understanding of each traders collective as organisations - seen as responses to the nature of their constituency (a spatially scattered, sometimes mobile, always fluid and precarious, multi-sites informal membership); to a competing political market where attracting new members is key to gain legitimacy and traction in the eye of the municipality. These organisational politics - stemming from classic and perhaps formal questions on organisational structures- are, we argue, responsive to the informal nature of trading politics, and the spatial configuration of inner city trading spaces. Here, an analysis of street trading organizations as social movements - dynamic institutions shaped by structures of opportunities, resources mobilization and framing processes; marred by processes of organization and leadership- is of particular relevance.

Figure 4 - Comparative profile of street trader organizations operating in inner city Johannesburg, 2014

\begin{tabular}{|c|c|c|c|c|c|}
\hline $\begin{array}{l}\text { Name of trader } \\
\text { organisation }\end{array}$ & Date of creation \& status & $\begin{array}{l}\text { Scale of } \\
\text { membership }\end{array}$ & Main trading sites & Identity & Political resource \\
\hline $\begin{array}{lr}\text { South } & \text { African } \\
\text { National } & \text { Traders } \\
\text { and } & \text { Retailers } \\
\text { Alliance SANTRA }\end{array}$ & $\begin{array}{l}2005 \text { splinter group from } \\
\text { ACHIB/ former Gauteng } \\
\text { Hawkers Association GHA? } \\
\text { Registered as NPO since } \\
2009\end{array}$ & $\begin{array}{l}\text { Claims } 3000 \\
\text { members }\end{array}$ & $\begin{array}{l}\text { Local - A few precincts } \\
\text { in the inner city. Strong } \\
\text { base around Park } \\
\text { station and the RID, } \\
\text { Yeoville }\end{array}$ & $\begin{array}{l}\text { Street traders inner } \\
\text { city }\end{array}$ & $\begin{array}{l}\text { Strong media network including social media. } \\
\text { Political networks at Provincial and national } \\
\text { network. Flirting with opposition party EFF. Links } \\
\text { with inner city growth coalition and legal } \\
\text { resources }\end{array}$ \\
\hline \begin{tabular}{ll|} 
South & African \\
Informal & Traders \\
Forum SAITF &
\end{tabular} & $\begin{array}{l}\text { 2006. registered as NPO } \\
\text { since } 2012 \text {. }\end{array}$ & $\begin{array}{l}\text { Claims } 9000 \\
\text { members }\end{array}$ & $\begin{array}{l}\text { Regional. In } \\
\text { Johannesburg, present } \\
\text { in formal markets }\end{array}$ & $\begin{array}{l}\text { Street and market } \\
\text { traders }\end{array}$ & $\begin{array}{l}\text { Strong partnership with legal NGO, which } \\
\text { provides training. }\end{array}$ \\
\hline $\begin{array}{l}\text { One Voice of All } \\
\text { Hawkers } \\
\text { Association }\end{array}$ & 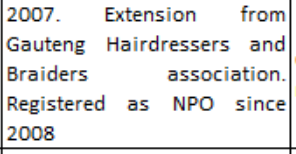 & $\begin{array}{l}\text { Claims } 3500 \\
\text { members }\end{array}$ & $\begin{array}{l}\text { Metropolican - strong } \\
\text { base around Park } \\
\text { Station, Joubert } \\
\text { Hillbrow, }\end{array}$ & Street trad & $\begin{array}{l}\text { Clientelistic relationship with City officials; } \\
\text { organises mass protests regularly. Some } \\
\text { political networks with the ANC and the EFF }\end{array}$ \\
\hline $\begin{array}{l}\text { Gauteng Informal } \\
\text { Development } \\
\text { Alliance GIDA }\end{array}$ & $\begin{array}{l}2011 \text { splinter from SAITF. In } \\
\text { process of registering as } \\
\text { cooperative. }\end{array}$ & $\begin{array}{l}\text { Claims } 650 \\
\text { members }\end{array}$ & $\begin{array}{llr}\text { Inner city } & \text { (Park } \\
\text { Station) } & \text { and } & \text { Soweto } \\
\text { (Kliptown) } & \end{array}$ & $\begin{array}{l}\text { Mobile traders, street } \\
\text { traders (inner city) }+ \\
\text { market and spaza } \\
\text { shoptraders }\end{array}$ & $\begin{array}{l}\text { Focus on individual economic development; } \\
\text { cooperatives. Links with global networks and } \\
\text { research entities }\end{array}$ \\
\hline $\begin{array}{l}\text { African Traders } \\
\text { Organisation ATO }\end{array}$ & $\left|\begin{array}{ll}2010 \quad-\quad \text { registered as } \\
\text { profitable org (Pty) } 2014\end{array}\right|$ & 280 & One street inner city & $\begin{array}{l}\text { Nigerian traders } \\
\text { selling second hand } \\
\text { clothes }\end{array}$ & $\begin{array}{l}\text { Strong business networks (customers from } \\
\text { Soweto and the continent). Some political } \\
\text { linkages to the workers party (WASP) }\end{array}$ \\
\hline $\begin{array}{l}\text { Nigerian Union of } \\
\text { Traders NUT }\end{array}$ & $\left|\begin{array}{l}2005 \text { - registered as } \mathrm{NPO} \\
2012\end{array}\right|$ & 175 & Four street inner city & $\begin{array}{l}\text { Nigerian traders } \\
\text { selling clothing }\end{array}$ & $\begin{array}{l}\text { Have been in those streets for } 15 \text { years legally. } \\
\text { Extremely organised, clean up campaigns, } \\
\text { emphasis on legality and partnership with City } \\
\text { officials }\end{array}$ \\
\hline $\begin{array}{l}\text { African Cooperative } \\
\text { for Hawkers and } \\
\text { Informal } \\
\text { Businesses ACHIB }\end{array}$ & $\begin{array}{l}1986 \text { under apartheid - } \\
\text { registered as cooperative } \\
2006\end{array}$ & $\begin{array}{l}\text { Claims } 33000 \\
\text { members } \\
\text { nationally }\end{array}$ & $\begin{array}{l}\text { National: mostly in } \\
\text { smaller municipalities. } \\
\text { Has lost prominence in } \\
\text { Johannesburg }\end{array}$ & $\mid \begin{array}{lr}\text { The first } & \text { trader } \\
\text { organisation } & \text { in } \\
\text { Johannesburg. } & \end{array}$ & $\begin{array}{l}\text { President of ACHIB also president of NAFCOC. } \\
\text { Strong political networks with the ANC at } \\
\text { national level, with the Ministry for Small } \\
\text { Businesses. Focus on economic opportunities } \\
\text { and development cooperatives }\end{array}$ \\
\hline
\end{tabular}

NB - Two existing organisations operating in Johannesburg inner city in 2014 are missing from this research: JOWEDET (a female dominated organisation), and SAHRA (specialising in traders operating in trains).

Whilst this picture masks organisations' fluidity, it emphasizes the fact that each organization has a history and an identity, quite vivid in traders' representations. Many are actually splinter groups from former organisations. More research is needed to retrace the history of these organizations, as many traders organizations operating in the mid-1990s have disappeared, morphed into others - see the Informal Business Forum, the Gauteng Traders association ${ }^{40}$, the Gauteng Hawkers Association ${ }^{41}$. Several trader leaders for instance have been working with ACHIB; its charismatic leader, Lawrence Mavundla, in spite of allegations of corruption, still commands respect from most traders, reinforced by his current position at the head of NAFCOC, a powerful national lobby for small business development and racial transformation, close to the ANC. 
ACHIB was formed in the mid-1980s under apartheid, as the regime was losing its grip on urban spaces, Black residents were informally moving into inner cities (filling the flats left vacant from the suburbanising white middle class), and trading started to appear in inner city streets. ACHIB fought the apartheid regime to guarantee traders the right to trade, and its leader found a loophole in the then ill-adapted street vending legislation - which allowed the holder of a trading permit to register other traders working under him. Lawrence Mavundla was then able to grant vending permits, under his name, to thousands of traders in Johannesburg: ACHIB grew exponentially as a consequence. The post-apartheid regime towards street trading however made ACHIB less necessary: national legislation gave traders full rights to establish themselves in inner cities. Then municipalities regained control and established stringent regulations, de facto restricting considerably the ability for street traders to trade legally in inner city ${ }^{42}$. ACHIB leadership (after some attempts to contest municipal legislation, partly through ugly in-fights, with xenophobic undertones, as a way of dealing with too scarce legal trading spaces for its membership) embarked on national politics, leaving local struggles to competing organisations that proliferated in the mid-2000s $\mathrm{s}^{43}$. These new organisations were not more successful than ACHIB in changing street trading municipal policy and practice; but they remained present on the ground to fight the most blatant municipal abuse, and use their power of blockage to at least ensure the persistence of the sector.

\section{Figure $\mathbf{5}$ - Nothing has changed in the last 10 years}

Particularly poignant and revealing are these two quotes from the same trader leader - the first in 2004 as an ACHIB leader, the second in 2014 as a SANTRA leader:

"ACHIB general secretary, Livingstone Mantanga, told SAPA the planned march followed ACHIB not having had a reply to a request by street vendors to meet with Sol Cowan, the councillor responsible for informal business issues, to discuss the removal issue. "Since last week, people have been removed from Bree and Wanderers streets," said Mantanga. He said that in May ACHIB had been promised that the council would host a "policy dialogue workshop" with the hawkers to debate and review council policies on their businesses. However, hawkers said they had not been given the opportunity to debate the policy documents before the council embarked on the "daily mass attacks on hawkers".

Source: SAPA 2003

"[...] Mr. Livingstone Mantanga [SANTRA Chair] visited the MEC's office this morning. The purpose for his visit was to submit a complaint about the informal traders who were evicted and their goods confiscated by Metro Police at President Street 2 weeks ago. [...] They indicated that they are willing to engage the City on the matter, however, their challenge is that the City is not willing to engage them. My mandate from the MEC's office is to request that you escalate the matter and for the matter to be given attention as soon as possible between the City and JMPD. Attached is the list of all traders that were removed from President Street by JMPD"

Source: Email exchange, Gauteng MEC and City of Johannesburg (communicated by SANTRA, 15 September 2014).

On this local terrain of the struggle, trader organisations have defined their own political niches fluid, straddling a variety of strategies and tactics shifting with political opportunities ${ }^{44}$, but having constructed, in the last decade, a reputation, a political culture, specific networks and repertoires of action. Their differentiation could be analysed along four related, but distinct, paradigms:

1) Whilst all the organisations mentioned here have a presence represent inner city street traders, their constituencies vary. SANTRA and One Voice represent almost exclusively street traders, and are 
often located in similar areas. They compete directly in Yeoville main street, around Park Station, and also have their more specific strongholds, around their main leaders' trading space: Joubert Park for One Voice, Retail Improvement District for SANTRA. SAITF represents a number of inner city street traders, but has also developed a presence in city markets, where a number of traders have been relocated in the early 2000s. It also has affiliates working in train stations, and has strong linkages with SAHRA, an organisation focusing on traders in trains. GIDA, a splinter group from SAITF and whose leadership intersects with One Voice's, encompasses inner city street traders but also mobile traders, as well as market and spaza shop traders in the townships. ATO and NUT are focused on a few streets in the inner city: ad hoc organisations defending the presence of Nigerian traders (the former specialising in second hand clothes in one street; the latter covering four streets where traders sell clothing, shoes and belts). These organisations, unlike the other, are protective rather than proactive, not looking to expand their constituency as much as to protect the status of their members in the inner city.

2) Linked to the previous variable, organisations have various spatial politics (see figure 6). They are all present in the inner city, competing for membership, as is the case between SANTRA and One Voice. However, whilst SANTRA focuses on the inner city, One Voice has developed other bases in former townships (Alexandra, Soweto) and new low-income developments (Cosmo City). SAITF, which had ambitions to federate all trader organisations, encouraged by a religious NGO (ESSET), has branches in various parts of Gauteng (Tshwane, Germiston, Vosloorus). GIDA, which was framed along similar lines under the influence of ESSET, has strongholds in the inner city, in Kliptown and in Lenasia - although it struggles to maintain this multi-site membership, after ESSET funding for mobilisation ended. ATO and NUT are very spatially specialised, holding a few streets or blocks with strong organisational unity and trading specialisation. ACHIB, as mentioned, as lost its grounding in Johannesburg - its members left feeling abandoned as the organisation focused less on their daily struggles and more on national politics. It still has branches in the East rand, but mostly focuses on smaller municipalities in South Africa, where the politics are less antagonistic to the state.

\section{Figure 6 - Spatial distribution of street trader organization membership in Gauteng}




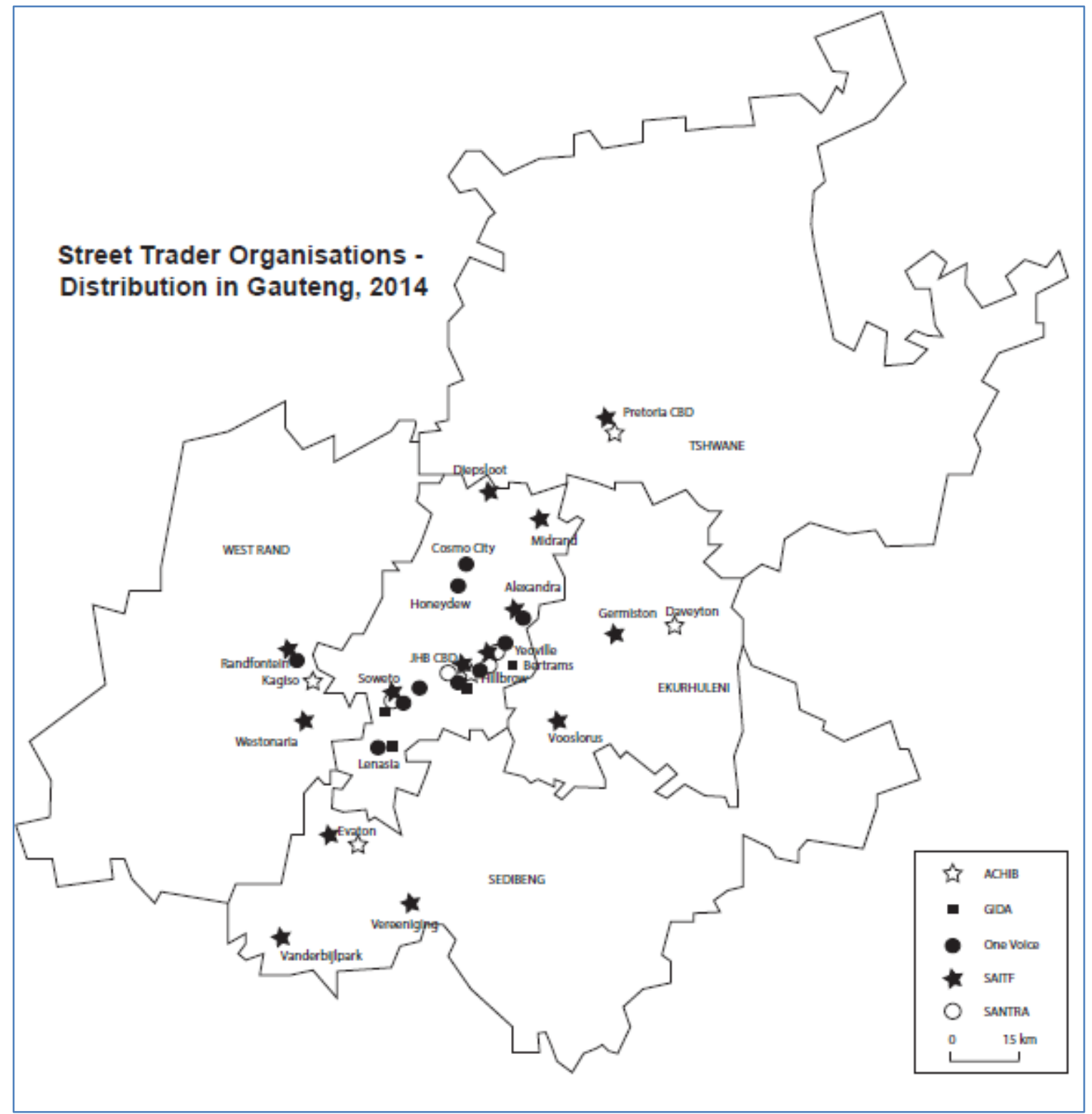

3) A third element of differentiated politics is the main focus and objective of street trader organisations, leaning predominantly towards economic development (negotiating traders' individual business training and support, forming cooperatives, developing access to credit or bulk buying, buying land or partnership with farmers, applying for government tenders, etc.), or focusing mostly around policy and legislation (fighting police abusive practices; resisting eviction and attempting to guaranteeing security of tenure for trading spaces, or increasing the number of legal trading spaces; negotiating municipal services and infrastructure around trading spaces; setting up forms of traders self-management or management partnerships).

ACHIB has moved from the latter to the former, based on limited success when antagonising municipal policies, and better prospects of success, thanks to its leader's ANC networks, in adopting the lines of economic development and racial transformation of entrepreneurs, a theme increasingly prominent in ANC discourse and in national policies. ACHIB turned to the national level, lobbying for economic development support for the sector, establishing networks with the state and party to open the vast markets of state tenders to the informal economy ${ }^{45}$, and finding public support to build traders' and producers' cooperatives. GIDA, networked with global NGOs and national and 
international research and advocacy networks, is also openly avoiding issues of trading policies, trying to set up cooperatives, establish transnational trade networks, lobbying at national and regional level for legislative change around cross-border trade.

At the other end of the spectrum, SANTRA, SAITF and One Voice are fighting on the ground for the protection of their members' right to trade - SAITF having shifted from a more economic developmental agenda (formerly supported by ESSET, encouraging the formation of cooperatives) towards a policy agenda (now turning to SERI, a legal NGO, or training and education around their rights).

NUT and ATO, with their foreign members, are in between: not entitled to claim any state benefit or developmental subsidy, but also more astute and educated businesspeople, their mandate is to protect their members' right to trade where they are, without openly antagonizing the state.

4) A fourth element, related to the previous but distinct, is the position of street trader organisations between antagonistic and cooperative engagements with the municipality. Of course all organisations use various modes depending on opportunity ${ }^{46}$, and antagonism- cooperation is to be thought as a continuum rather than a stark binary: but historically, some organisations are building a profile of cooperation, others are constructing their identity around their ability to fight. Operation Clean Sweep has been a turning point in this respect, where trader organisations have had to position themselves officially, in favour or against the court case. SAITF and SANTRA have filed two independent court cases against the City and taken the lead in antagonising the City; it was at this time that ATO had affiliated to SAITF, and has been instrumental in constructing the link between SAITF and SERI, the supporting legal NGO. One Voice has officially opposed the idea of litigation against the City; GIDA was still trying to find negotiated solution; NUT, playing the compliance and legality card or its foreign members, was not in a position of overtly antagonise the City. Of course, these official positions against litigation have not prevented organisations to register their members under SAITF or SANTRA traders' lists submitted to the court. Thus, some One Voice members can be found under SAITF traders list; NUT had approached SANTRA and provided their members' names to be included in SANTRA's list.

Analyzing organisations according to their repertoires of action is useful to further analyse their position in this continuum, between formal and informal modes, rights and clientelistic discourses and practices. SANTRA has a long standing public discourse on "the people's economy", has developed expertise on policy and legal documents, and is quick to use social media and the press to denounce abuse and illegal behaviour by the police in particular, using a language of rights and economic development. SAITF is recently developing, under the patronage of SERI, a discourse of rights across a variety of policy and legal documents. Both organisations however (see below) are also attempting to propose formal partnerships with the City of Johannesburg, in terms of management of specific trading spaces (the Retail Improvement District streets for SANTRA; Johannesburg markets for SAITF), SANTRA having allied for this matter with the Central Johannesburg Partnership, a coalition of inner city based private companies encouraging the creation of City Improvement Districts with forms of private urban management. Their leadership use mostly formal types of engagement, both in antagonizing and cooperating with the City.

On the other end, GIDA leaders express that "we are not doing politics", and are working closely with City officials as a result of this loyalty, through informal networks of information flows. One Voice is 
known for its strong clientelistic networks with some municipal officials, enabling the organisation to have some privileged access to trading spaces for its members. Which does not prevent One Voice to regularly use the repertoire of mass protest- far more than SANTRA and SAITF, whose more educated and literate leadership is better able to navigate the legal, policy and petitioning system than One Voice, and who maintain that protests are inefficient in influencing the municipality (even though the threat of violence, and in particular xenophobic violence, has a degree of political efficiency ${ }^{47}$ ).

ATO and NUT, the two foreign traders based organisations, have interestingly different politics. NUT is over-emphasising good citizenship and legality. "Over-compliant" to all municipal rules, it maintains strong internal discipline: not trespassing legal trading spaces marked by yellow lines painted on the pavement; suspending trading once a month for cleaning campaigns; leveraging fees from members to capacitate some admin and organisational capacity; working with the police against crime. NUT also publicizes its contributions to the South African society through fundraising campaigns, food and clothing donation, partnerships with South African schools. ATO, headed by a South African leftist activist, joined the litigants during Operation Clean Sweep, but generally adopts a more cooperative discourse around business: having "made" de Villliers street a second hand clothing hub, they emphasize their business skills when engaging with City officials.

Straddling the antagonism-cooperation continuum and the rights-favour continuum is also done through engaging various levels or sections of the state, and attempting to play one against the other - and partly explains spatial politics. This is not unique to South Africa ${ }^{48}$ : street trading is a function shared by various municipal departments (economic development, planning and community services) and various tiers of the state (national and local). But this might be particularly acute in contemporary South Africa, still marked by a dominant party system, where party competition is limited, and competitive politics occur rather inside the liberation party, between factions or tiers. Street trader leaders navigate these politics, when they chose to antagonise the (ANC-led) municipality, by engaging more cooperatively with other (ANC-led) levels of the state, at Provincial and National levels, whose policies and practices are generally more sympathetic to street trading, seen as contributing to poverty alleviation, without having to bear the responsibility of managing the streets and regenerating the inner city to attract private investment. ACHIB has officially redirected its efforts towards the national level, abandoning antagonism against the City; GIDA is also developing linkages with the national Ministry of Small Businesses. In the context of political competition between provincial and local government, SAITF as SANTRA have attempted to mobilise the former against the latter ${ }^{49}$. This strategy has had limited success: the strong Johannesburg City Council continues to lead the way, unabated by provincial government toothless oversight role, and provincial political party directives weakened by factional instability. This alliance with national and provincial governments has nevertheless allowed street trader organisations to demonstrate their loyalty to the ANC and not alienate themselves from the party. However, even this necessity might be fading, with the rise of competitive politics and the ANC electoral decline in Johannesburg.

Adopting a social movement lens to the analysis of street trader organizations in Johannesburg has helped making sense of their diversity as well as their complementarity, using or framing selective niches in a spectrum of political opportunities, straddling antagonism and cooperation at multiple scales of the state, around a continuum of issues between economic empowerment and political 
enfranchisement. What remains to be added to this too static picture is how organisations frame their boundaries, gain and maintain their membership, to support their claims to the city.

\section{Spatial politics and the issue of representation}

In this highly competitive context, where street trading organisations are hardly making significant progress policy wise - theirs is limited to a power of blockage and reaction against the most visible state abuse ${ }^{50}$ - organisations are struggling to maintain and grow their membership. For many of them, members constitute a resource: a financial resource when they manage to collect membership fees; a political resource when it comes to demonstrate legitimacy in the face of the municipality. In this context, it becomes interesting to interrogate how organizational structures are constructed to maintain their basis, and the strategies developed for attracting and nurturing their constituencies. This section will analyse organisational structures and management strategies, as framed in particular around the issue of traders' representation. Consolidating and claiming representativeness, in particular around specific spaces in the city, are indeed key for organizations to frame their claims to a "right to the city" - not only a place to trade legally, but also, perhaps more debatably, the right to decide on who trades and how, and to establish forms of self-management of trading spaces in the city.

Academic literature and activists (often coming from unionist background) blame street trader organisations' lack of internal democratic principles and procedures for their failure to upscale and gain significant political influence ${ }^{51}$. Whilst more democratic structures and processes would be ideal, they possibly do not pay sufficient attention to the way these organisations work practically. As Houtzager and Lavalle demonstrate ${ }^{52}$, most civil society organisations in the developing world lack formal representative-ness and democratic accountability. Yet, they have claims to representativeness that it seems abusive to discard too quickly because it does not fit theoretical principles and normative liberal expectations. The authors call for alternative understandings of representativeness in cities of the South, to account for the work these imperfect, 'unrepresentative' organisations do.

In Johannesburg, as elsewhere, most trader organisations do not hold elections nor regular meetings, and are headed by self-appointed leaders (or leaders elected once with a never-ending mandate), using personalized politics. This is a reason used by the City of Johannesburg to interact rather with block leaders - supposedly elected at the block level by small groups of traders. These block leaders used to attend the Informal Traders forum, but also meet City officials in specific block traders meetings, where everyday issues are solved. Some have apparently some leverage in allocating trading spaces in their streets, keeping informal street trading waiting lists in agreement with officials. They are often seen by organisation leaders as competition, co-opted by the City and therefore unable to confront its repressive practices. Block leaders do not seem more "democratic" in their practices than organisation leaders (the regularity of their elections can be questioned), and are not in a position to antagonize overtly the City; but their fine reticulation of trading spaces ensures that each legal trading block is represented in public meetings, and their direct presence on the ground means that they represent a recourse for traders, in a form of accountability that can be seen as a key dimension of local democracy. 
1) Leadership and organizational structure -reticulating the organisation in scattered spaces, nominating leaders with their constituencies

In spite of the diversity of their status (some are registered whilst most are in the never-ending process of registering; some are registered as non-profit organisations, some as cooperatives, some as private companies, a few want to open a trust), all organisations have formed executive committees, in more or less formalised and systematic ways, which share a number of features. All are headed by strong, personalised male leadership (a chair and his committee), with committee members often representing a local constituency. This reticulation constitutes a form of decentralization (each area has its representative, aware of local issues, a recourse point immediately accessible to traders); as well as a mobilisation strategy - each leader bringing 'his/her' constituency into the organisation, and being rewarded by a position in the committee.

SAITF for instance, an aspiring forum for several organisations (called "affiliates"), has a national committee (within which various branch leaders are represented), and local branches. A Tshwane branch was disbanded, but a Gauteng branch is up and running. The executive committee members are chosen for their dedication to the forum and for their position as heads of affiliates.

One Voice, chaired by less educated leadership, also long term traders and activists, has a less extensive and formal structure, that nevertheless follows similar principles: a strong personalised leadership consisting of the "President", his right arm, a deputy chair, and a number of "area representatives", grounded in other areas where One Voice has a membership basis: Cosmo City, Diepsloot, Alexandra, Yeoville.

GIDA is a collection of leaders of organisations - the chair of Kliptown market traders association; of Lenasia market traders; an executive member of an association of spaza shop owners of Soweto; inner city block leaders. This small committee, meeting regularly, is able to claim a variety of spatially scattered constituencies.

SANTRA, more concentrated geographically in the inner city Johannesburg, has not set up such reticulated forms of leadership: most of the members of its executive committee are based around Park Station, in close spatial proximity to one another and in the most lucrative, busiest parts of the City. They have informal representatives in other areas (such as Yeoville), but with no mandate and limited role in the organisation, beyond relaying information to the committee.

ATO and NUT have different structures. Smaller organisations occupying streets with limited competition, their structure does not need geographic representation, but is reflective of strong regulatory and disciplining functions they need to perform to gain legitimacy and keep a low profile in the City. They have established dedicated task teams to collect the members' fees, solve conflicts, monitor traders' behaviour, organise cleaning days, check security, call for meetings. They deal with leadership change through the nomination of an advisory team, honorary positions that enable former leaders to still be part of the executive, to defuse internal conflict.

Insert Figure 7 (1-3) - Selected street trader organization leadership structures: SAITF, One Voice, NUT, 2014 

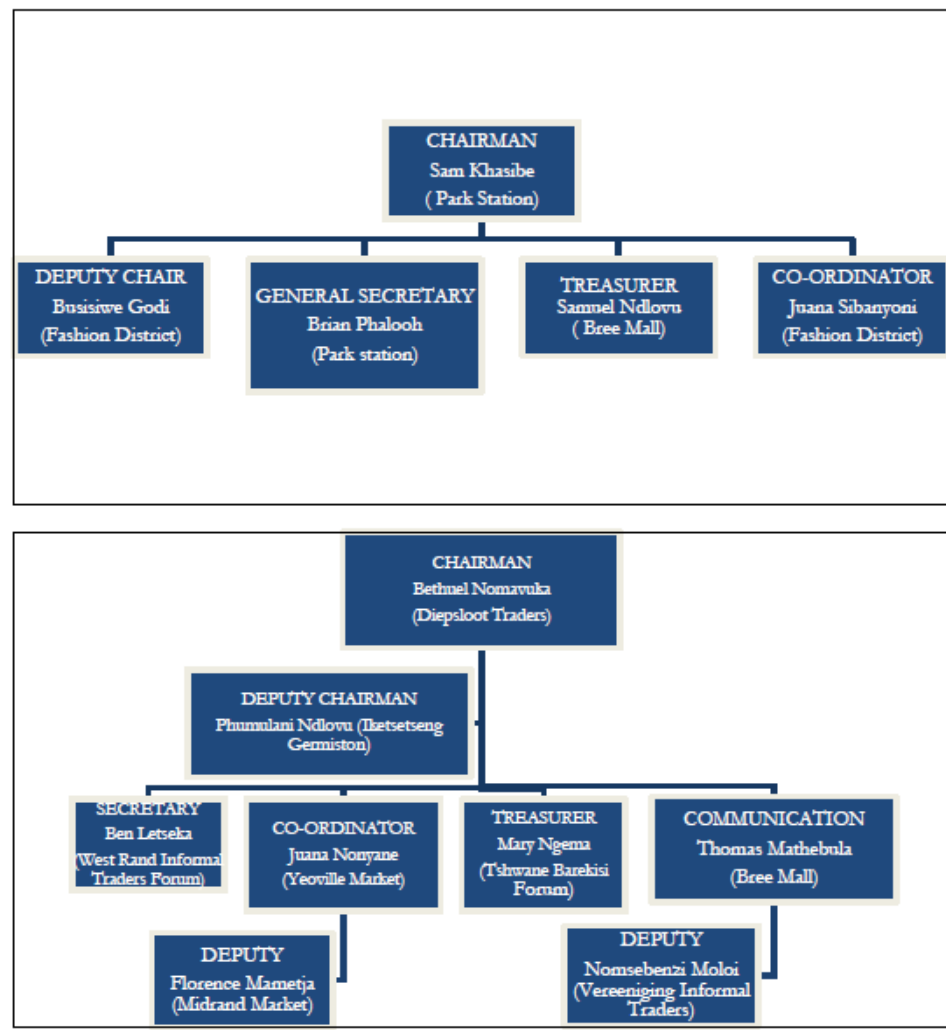

Figure 7.2. One Voice organogramme, 2014
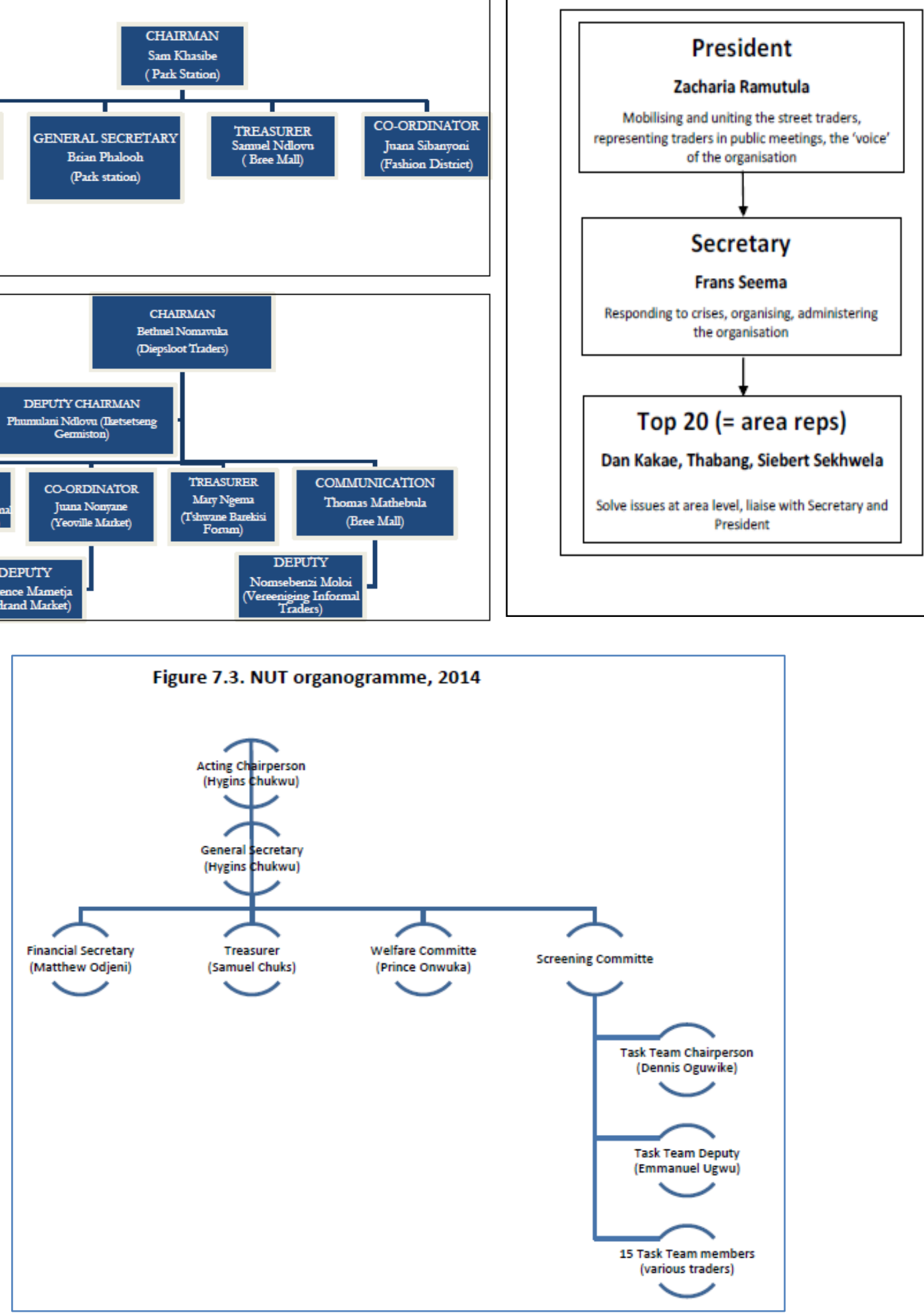

Incorporating representation from a variety of areas in organisations' committees consolidates loyalty and allows for the circulation of information in spatially scattered constituencies. Sometimes, these grounded leaders coincide with inner city block leaders, and organisations, in spite of their public criticism of the co-opted block leaders, incorporate some of them in their committee. This 
gives them some access to municipal information passed on to block leaders. However, area or organisational representation is not always automatic, leading to internal tension. For instance, ATO joined SAITF as an affiliate, during Operation Clean Sweep, as they felt they would be stronger as part of a bigger, South African trader organisation. ATO leader however soon complained about being excluded from strategic meetings, and claimed a position in the committee, which was denied on the grounds that it was not election time: ATO would have to wait and demonstrate commitment to the organisation. This led ATO to secede from SAITF and claim representation on their own, in particular in negotiations with the City and with the legal NGO, SERI.

\section{2) Limited opportunity for meetings: how to maintain organisational unity?}

The scarcity of general meetings presents a challenge for the maintenance of organizational unity. Calling for general meetings of traders is problematic, more than any other civil society organisation, as membership is based on the workplace, not the place of residence. Afterhours meeting are therefore difficult (traders need to catch their transport to go home); meetings during the day detract from business and have real economic consequences on the traders' daily income.

Few trader organisations are able to hold regular meetings. NUT and ATO, due to their small scale and spatial concentration, do so monthly. Through membership fees, they are able to rent office space, formally (for ATO) or informally (renting a bar, for NUT). Their status as foreign traders might also make these meetings more necessary, as they are confronted to a variety of threats. Other organisations do not hold regular meetings. GIDA used to, when it was supported by ESSET with transport money, but this funding has been suppressed; they continue holding committee meetings on a monthly basis, hosted by a local church. SAITF, under the influence of SERI's regular training sessions with its leadership, is consolidating its structure and holding more regular collective meetings, at least in Johannesburg. SANTRA, setting up a formal partnership with CJP, is also strongly encouraged to follow corporate governance principles. But these attempts do not fundamentally address the issue - it is challenging to organise traders meetings, as it directly compromises traders' income-generation. How do organisations then maintain links and networks with their members?

Few use social media, beyond the small circles of executive members. Mostly, networks are maintained through area-based representatives, accessible physically to their local members; and through direct contact with highly mobile leadership. This requires dedicated time, and means that some organization leaders are not, or no longer, street traders themselves: as is the case for SANTRA, One Voice, and SAITF chairpersons. They sometimes receive a stipend from their organisation, or employ someone to attend to their stall or shop; they spend their time navigating the various trading areas where they have membership, to attend to local issues and maintain the network.

Other means of maintaining the organisation's identity are moments of collective mobilisation. For One Voice, mass protests are possibly more a branding device, to consolidate its own ranks, than aimed at confronting the City. With the "President" holding a loud hailer and leading the march, marchers in full One Voice regalia with T-shirts, posters and pamphlets distribution, protests are key moments of visibility of the organisation, demonstrating its own collective power. In a similar vein, the City-chaired Informal Trader Forum (ITF), that used to be attended by a variety of street traders leaders from all trading locations in Johannesburg, was mostly a place of spectacle, where various leaders competed for visibility and reaffirmed their organizational identity, rather than using it for deliberation and strategic engagement with the City. 
The nature of street trading constituency, work-place based and spatially scattered, impacts on organisational politics and representativeness. It reinforces the personalisation of leadership mobile leaders touring various membership areas, solving issues, favouring face to face contacts, managing local politics. They maintain networks and visibility of the organisation, but do not provide places of collective debate and deliberation. Accountability is not judged on a collective basis and on strategic organisational positions: it is judged according to results - the ability of organisation in protecting and defending its members, in securing, even if always with a degree of uncertainty and temporariness, their trading spaces.

\section{3) Securing trading spaces, claiming self-management: consolidating the organisation's} power

In a context of scarce legal trading spaces (trading licences as well as demarcated trading spaces), organisations indeed struggle to secure trading spaces to their members. It takes the form of competing amongst themselves, as during Operation Clean Sweep, or through the constant delegitimation of other organisations, in particular foreign traders' (NUT and ATO) whose access to trading licences and spaces is regularly questioned as based on corruption. During the attempted negotiation after Operation Clean Sweep, some leaders suggested that foreign traders should only be allowed $20 \%$ of all legal trading spaces. Xenophobia is rife in traders' discourses - as in particular many foreign traders, barred from accessing legal trading spaces, set up unauthorised trading stands in better locations, or with a higher degree of mobility, or even in front, of South African legal trading stalls. This conflation of nationality, scarce legal trading spaces and often higher level of education and trading skills of foreign traders, lead to high levels of competition that South African traders capture under the paradigm of xenophobia, calling for more enforcement against unauthorised trading and the intervention of Home Affairs in the process. This was the case during Operation Clean Sweep, where the City called Home Affairs officials to participate in the verification process, checking not only trading licenses but also residence documents, and often discarding foreign traders trading licenses.

Access to legal trading remains indeed obscure, and is likely to involve a level of discretion and bribery in the context of restricted authorised trading spaces. Limited information is given by the City on people applying for trading spaces: some traders report the existence of a trading waiting list, that block leaders compile together with street level city officials, giving them some discretionary power ${ }^{53}$. Trader organisations adopt other strategies, mobilising unauthorised traders gathered in specific streets or blocks, and lobbying for their legalisation, with sometimes a degree of success. The difficulty for organisations, then, is to retain the loyalty of these new members:

"The City tells our members 'don't join the organizations: this is the City's street, not One Voice's. They will ask the block to elect their block leader, call all block leaders to meetings without calling organizations. So, our members tend to stop supporting us, even if it is because of us that they are now trading legally". (One Voice leader 2014)

For trader leaders, the City uses block leaders to deliberately undermine street trader organisations, by creating an alternative layer of leadership with a tight spatial grip on trading spaces, and a propensity to be loyal to the City that gives them leverage. Yet, organisations claim that they are the ones with the strategic ability to raise broader issues and lobby for more legal trading space - an ability not shared by block leaders due to their structural position. 
"When the City builds markets for traders, they say 'we don't negotiate with organizations, we talk to traders and block leaders. Elect a committee and we will engage with that committee. We can't talk to you as SAITF'. But we as SAITF are the one raising issues here, and as a result the City ends up talking to us" (SAITF leader 2014).

Beyond raising issues and contesting the City's restrictive approach to street trading (pragmatically as well as policy-wise), trader organisations are indeed attempting to set up self-management models for the various spaces in which they are grounded. It reflects a desire to better responding to traders' needs, and possibly a way of claiming citizenship ${ }^{54}$, or a "right to the city" - both in terms of place, recognition and legitimation as traders, but also in terms of collective appropriation of space and claimed entitlement to decide on the local governance rules, in ways that could reflect what Castells framed, for other types of movements, as struggles for collective consumption and for political selfdetermination ${ }^{55}$. It is also a practical way to brand a space of authority and unify membership in that specific trading space; a means of raising organisational funding through a levy that a formal partnership or a delegation by the City would render compulsory.

NUT has successfully, although not without internal contestations, implemented forms of trading self-management, in their strategy to be "model traders" in the eyes of the City. This was possible because of the spatial concentration of NUT members, in four streets (straddling a few blocks each); the high level of organisation of NUT; NUT leaders also featuring as block leaders (NUT chairperson is also the area chair for block leaders in this part of the inner city), and participating in Community Policing Forum, in partnership with the police. Collecting relatively high fees from traders in the four streets, on a monthly basis, NUT is able to keep an informal database of traders, their payment level, their products; to organise monthly cleaning days where trading is suspended; to maintain a high level of attendance to meetings; to solve a number of issues with the City (thanks to the block leadership position) as well as with the police (thanks to the participation in CPFs). If leadership positions are contested within NUT, in particular around budget issues, NUT has succeeded in maintaining unity and direction for the organisation; and seeing their trading spaces relatively secured by City officials in the contest of xenophobic pressures from other traders. However, this delegation of authority remains informal - tolerated, used by City officials to have the streets effectively managed, but fragile in case of conflict. It is also only possible because it is small scale and there is a relative unity amongst traders in these four streets - with limited competition from other street trader organisations, leaving NUT to claim management leadership without more than occasional individual contestation.

One Voice, whose leader was the chairperson of Gauteng Hairdresser and braiders association, less successfully attempted to claim the management of a building where he had worked hard to relocate and legalise local street hairdressers. A pragmatic negotiation with an inner city developer and property owner, City Prop, could have led to an agreement giving One Voice the power to collect the rent and claim membership of all hairdressers.

"We successfully negotiated a building with City Prop, to relocate the hairdressers operating in the street. We reached an agreement with them, that One Voice would collect the rent for City Prop from hairdressers, and even keep a portion of the rent for the organization. We had an agreement. But the City interfered, they told City Prop not to deal with One Voice, they blocked us. But the building was earmarked for hairdressing because of us! Hairdressers who were trading illegally in the streets are now legal in the building because of us!" (One Voice leader 2014) 
A more successful partnership between inner city private companies, interested in having street trading managed in their vicinity, and trader organisation leaders, is currently being proposed to the City of Johannesburg. Based on an existing experience of street management model in the Retail Improvement District, where the management of traders was delegated to the private sector with a degree of formalization ${ }^{56}$, both trader and private sector local organisations, and the Central Johannesburg Partnership (CJP), are jointly consolidating a model of street trading management around Park Station, that they propose to jointly manage. The issue is that Park Station is not only host to SANTRA members; One Voice and SAITF also claim membership in the area - but CJP is far less keen to partner with these more unruly trader associations (one seen as leftist and the other as populist). These complex issues of representation in such a dense trading areas, where several trading organisations compete for membership, are an important challenge to the model, in practice but also in principle.

These practices and proposals raise a key dilemma, reflecting the dual dimension of representation ${ }^{57}$ : representation as reflection (the representative being 'one of us') and representation as political efficiency (the representative being 'the most able to defend our interest'). In a way, this contradiction is embedded in the difference, presented earlier, between locally elected block leaders (with limited structural and personal capacity to raise strategic issues to the City), and street trader organization leaders (some of which have become professional organizers and are no longer trading). This contradiction is amplified by the very nature of street trading spatial politics. In Johannesburg, no trading space is dominated by one single trader organization (except where specialized trading prevails, like the blocks managed by ATO and NUT). There is therefore a balance to be found between local accountability and freedom of association (which requires locally elected leaders and committees); and political efficiency and strategy (which requires empowered organizations, able to raise issues, understand stakes, put pressure and strike deals ultimately benefiting the sector as a whole). Examples of trader-managed markets across the world offer various forms of resolution of issues of representation, where market committees often offer a mix between area-based elected representatives with nominated leaders- with various effects on the democratic (or not) and inclusive (or not) nature of this form of management ${ }^{58}$. Examples of trader-managed streets are less widely documented - those which are generally work, like NUT, at a relatively small scale.

Street trading organisations' claims for trading space in the inner city can be read as their fundamental "right to the city" - as marginal workers constantly working under the threat of eviction, yet making a living by accessing central spaces as public urban goods; as "informal people" seeking recognition, respect, and participation in the decisions affecting their lives and livelihoods, at city, precinct or street scales. Yet, as entrepreneurs, de facto appropriating public space for their individual profit, effectively privatizing inner city streets, in highly competitive ways, their claims for self-management of trading spaces raise questions and highlight the limitations of an approach of traders' struggles in terms of "right to the city". Whilst forms and models of participation of street traders in the management of their own trading spaces remain to be explored, tested and consolidated, and do open the way for more inclusive and democratic cities, these initiatives need to be framed with two key questions in mind, not dissimilar to those asked about City Improvement Districts in the neoliberalising governance of contemporary cities: can the governance of public space be delegated to (big or small) entrepreneurs? How would the right of freedom of association be respected, and how would the delegation of the right to levy trading rents and allocate trading 
spaces, not turn into an undemocratic practice, if such authority was delegated to a specific trading organization, within a specific space?

\section{Conclusion}

The analysis of street trader organisations through the lens of the social movement literature has opened to the ambiguities of street trader organisations' claims for self-management of discrete trading spaces. These claims are a response to the difficulty of establishing meaningful engagement with a consistently deceiving municipality; they are also a reflection of political and organizational needs, where most organisations need to consolidate their membership, their legitimacy and their financial resources in highly diverse, competitive and fluid spaces. Here, the multiplicity and complementarity, as well as the partial overlaps and competition, between each organisation's political niches (in terms of constituencies, scale and focus of action, as well as strategies of engagement with the state), help understanding the difficulties in fostering political unity for what is still often described as a sector, and is definitely sharing a number of collective grievances, concerns and claims in the city.

The case analysed here is however not one of successful mobilization and unity in the trading sector. Operation Clean Sweep, instead of fostering unity amongst trader organization against the municipality, has entrenched deep divisions and resentment, difficult to overcome in the post Operation politics.

Attempts to build the sector's unity were weakened by deep distrust towards any agent claiming legitimacy in this respect - none of the seven competing organizations, no matter how national they claimed to be, had the legitimacy to do so. A number of external organisations attempted, not more successfully, to unify the sector at this occasion. The federation of trade unions, COSATU, provided support and advice, but was too caught in its own politics to be trusted (in the context of crisis of the Alliance with the ANC). ESSET, a Christian NGO involved in supporting the sector, had been accused by some trader organizations it had supported over time, to use them in order to raise funds and gain legitimacy towards its own funders. Streetnet, a global NGO working with international organisations to raise the profile of informal trading in international and national agendas, was seen by some as competing to capture local leadership, and was possibly lacking local implementation, in spite of the organizational resources it offered. CUBES, a research entity based as Wits University, was not equipped nor mandated to develop the needed trader organizational skills, beyond providing a platform for trader organizations to debate City's moves, in times of urgency. SERI, the legal NGO leading the court battle, was focusing on its client (SAITF), and promoting a necessary but quite specific type of empowerment - legal, rights based and antagonistic to the city, that did not fit all traders nor all trader organisations.

What this story opens to are fundamental and critical issues of representation. Beyond the question of the political unity of the sector (a perhaps unattainable objective in the context of consolidated antagonism and complementary political niches), issues of representation constitute real, lived dilemma embedded in street and market trading governance - beyond abstract dreams of liberal democratic rules and accountability. The conundrum of trader representation, between the political efficiency of more autonomous street trader organization leadership, and more directly elected but nested in municipal networks block leaders, has serious effect on traders' ability to propose efficient and democratic models of street trading management where they would play a part. It is certainly 
instrumentalised and aggravated by municipal divisive politics; but it is also reflecting a fundamental tension within the concept of representation itself, whose practical resolution can take many forms. Here, reading street trading politics along trade union literature might be a productive avenue for further reflection. Learning from union politics at the workplace, the construction of workers' solidarity and the management of competitive, factional or centrifugal tendencies (certainly encouraged by employers), for the sake of political efficiency - might be useful to better understand, in their commonalities and differences, the possibilities and limitations of more united collective claims for a place in the city.

\section{References}

Anjaria, J. "Ordinary states: Everyday corruption and the politics of space in Mumbai". American Ethnologist 38, no. 1 (2011): 58-72. DOI: 10.1111/j.1548-1425.2010.01292.x

Bayat, A. “'Un-Civil Society': The Politics of the 'Informal People'”. Third World Quarterly 18, no 1 (1997): 53-72. DOI: Ol43-6597/97/(WX)53-20.

Bénit-Gbaffou, C. "Operation Clean Sweep, (not) managing street trading in post-apartheid Johannesburg. Have South African cities become ungovernable?". Paper submitted to Journal of Development Studies, October 2015.

Bénit-Gbaffou, C. In quest for sustainable street trading management. Lessons for Johannesburg post Operation Clean Sweep. Research report. Johannesburg: CUBES, Wits University, 2015. http://www.wits.ac.za/files/ajrbf 575286001429804134.pdf

Bénit-Gbaffou, C. (ed.). A political Landscape of Street trader organisations in inner city Johannesburg, post Operation Clean Sweep. Edited Planning and Politics students research report. Johannesburg: CUBES, Wits University, 2014. http://www.wits.ac.za/files/ajrbf 194844001429803758.pdf

Bénit-Gbaffou, C., and O. Katsaura. "Community leaders and the construction of political legitimacy. Unpacking Bourdieu's political capital in post-apartheid Johannesburg. International Journal of Urban and Regional Research 38, no 5 (2014): 1807-1832. DOI:10.1111/1468-2427.12166

Bromley, R. "Street Vending and Public Policy: A Global Review." International Journal of Sociology and Social Policy 20, no. 1-2 (2000): 1-28. DOI: 10.1108/01443330010789052.

Brunette, R., I. Chipkin, G. Tshimomola, and S. Meny-Gibert. The Contract State: Outsourcing \& Decentralisation in Contemporary South Africa. Research report. Johannesburg: Public Affairs Research Institute (PARI), 2014.

Castells, M. The city and the grassroots: a cross-cultural theory of urban social movements. London: Edward Arnold, 1983.

Chatterjee, P. The Politics of the Governed: Reflections on Popular Politics in the Majority of the World. New York: Columbia University Press, 2004.

Celik, E. Rethinking street traders as promising agents of re-empowering labour movement in contemporary South Africa. Global Labour University Conference 'The Politics of Labour and Development', 28-30 September 2011, Johannesburg, South Africa. http://www.global-labouruniversity.org/fileadmin/GLU conference 2011/papers/Ercuement Celik.pdf.

Devenish, A., and C. Skinner. "Collective Action in the Informal Economy: The Case of the Self Employed Women's Union, 1994-2004". In Voices of Protest: Social Movements in Post-Apartheid South Africa, edited by R. Ballard, A. Habib, and I. Valodia, 255-278. Pietermaritzburg: University of KwaZulu-Natal Press, 2006.

Dobson, R. and C. Skinner. Working in Warwick: Including Street traders in Urban Plans. Durban: UKZN, School of Development Studies, 2009.

Gallin, D. "Propositions on trade unions and informal employment in times of globalization". Antipode 33, no. 3, (2001): 531-549. DOI: 10.1111/1467-8330.00197 
Grest J. Statutory Representational Systems at Local Government Level: Ahmedabad, India. Report for Streetnet International, 2012. http://www.streetnet.org.za/docs/research/2012/en/Grest AhmedabadReport.pdf.

Holston, J. Insurgent Citizenship: Disjunctions of Democracy and Modernity in Brazil. Princeton and Oxford: Princeton University Press, 2008.

Horn, P. Collective Bargaining in the Informal Economy - Street Vendors. Report for WIEGO, 2014. http://www.streetnet.org.za/docs/research/2014/en/cb report.pdf.

Horn, P. Summary report: Case studies of collective bargaining and representative forums for street traders. Streetnet International, 2012. http://www.streetnet.org.za/docs/research/2012/en/composite.pdf.

Horn, P. From best practice to Pariah: the case of Durban, South Africa. StreetNet News No. 6, September 2005, 5-7. http://www.streetnet.org.za/docs/newsletters/2005/en/Streetnetnews61.pdf

Houtzager P. and A. Lavalle. "Civil Society's Claims to Political Representation in Brazil". Studies in Comparative International Development 45, no. 1 (2010): 1-29. DOI 10.1007/s12116-009-9059-7.

Kamete, A.Y. "Defending illicit livelihoods. Youth resistance in Harare's contested spaces". International Journal of Urban and Regional Research 34, no. 1 (2010): 55-75. DOI: 10.1111/j.1468-2427.2009.00854.x.

Kamete, A.Y. and I. Lindell. "The politics of "non-planning" interventions in African cities: unravelling the international and local dimensions in Harare and Maputo". Journal of Southern African Studies 36, no. 4 (2010): 889-912. DOI: 10.1080/03057070.2010.527643.

Kumar, R. The Regularization of Street Vending in Bhubaneshwar, India: A Policy Model. WIEGO Policy Brief (Urban Policies) no. 7, 2012. http://www.inclusivecities.org/wp-content/uploads/2012/09/PB7 Kumar 3.pdf

Lindell, I., ed. Africa's informal workers. Collective agencies and transnational organising in urban Africa. London: Zed Books, 2010.

Lindell, I. "Between Exit and Voice: Informality and the Spaces of Popular Agency". African Studies Quarterly 11, no. 2\&3 (2010): 2-11. ISSN: 2152-2448.

Lindell, I. "The Multiple Sites of Urban Governance: Insights from an African City". Urban Studies 45, no. 9 (2008): 1879-1901. DOI: 10.1177/0042098008093382.

Lindell, I. and J. Appelblad. "Disabling governance: Privatisation of City markets and implications for vendors associations in Kampala, Uganda". Habitat International 33, no. 4 (2009): 297-404. DOI: 10.1016/j.habitatint.2008.12.001

Lyons M., A. Brown and C. Msoka. “(Why) Have Pro-Poor Policies Failed Africa's Working Poor?”. Journal of International Development 24, no. 8 (2012): 1008-1029. DOI: 10.1002/jid.2876.

Matjomane, M. Strategies used by Street Traders' Organisations to Influence Trading Policy and Management in the City of Johannesburg. Unpublished Master Thesis, Urban Studies. Johannesburg: Wits University, School of Architecture and Planning, 2013.

Meagher, K. "The politics of vulnerability: exit, voice and capture in three Nigerian informal manufacturing clusters". In Africa's informal workers. Collective agencies and transnational organising in urban Africa, edited by I. Lindell, 16-64, London: Zed Books, 2010.

Morange, M. "Street trade, neoliberalisation and the control of space: Nairobi's Central Business District in the era of entrepreneurial urbanism". Journal of Eastern African Studies 9, no. 2 (2015): 247-269. DOI: 10.1080/17531055.2015.1018407.

Motala, S. Organizing in the Informal Economy: A Case Study of Street Trading in South Africa. ILO research paper, 2002. http://www.ilo.org/wcmsp5/groups/public/@ed emp/@emp ent/@ifp seed/documents/ publication/wcms_117700.pdf.

Pillay, D., and L. van der Walt. "Introduction: Assessing the Politics of Organized Labour in Asia, Africa and Latin America at the Start of the 21st Century". Travail, capital et société 44, no. 2 (2011): 2-25.

Pitkin, H. The Concept of Representation. LA: University of California Press, 1967. 
Simone, A. "People as Infrastructure: Intersecting Fragments in Johannesburg". Public Culture 16, no.3 (2004): 407-429. DOI: 10.1215/08992363-16-3-407

Sinha, S. and S. Roever. India's National Policy on Urban Street Vendors. WIEGO Policy Brief (Urban Policies) no. 2. (2011). http://wiego.org/sites/wiego.org/files/publications/files/Sinha WIEGO PB2.pdf.

Skinner, C. Street Trade in Africa: A Review. WIEGO working paper 5, 2008. http://wiego.org/sites/wiego.org/ files/publications/files/Skinner WIEGO WP5.pdf

Thulare, P. Trading democracy? Johannesburg informal traders and citizenship. Research report, Johannesburg: Center for Policy studies, Policy: issues and actors 17, no. 1 (2004).

Von Holdt, K., M. Langa, S. Malopo, N. Mogapi, K. Ngubeni, J. Dlamini, and A. Kirsten. The smoke that calls: Insurgent citizenship and the struggle for a place in the new South Africa. Research report. Johannesburg: Centre for the Study of Violence and Society, Work and Development Institute, 2011.

Wafer, A. "Informality and the spaces of civil society in post-apartheid Johannesburg". In Critical perspectives on African Politics: Liberal interventions, state-building and civil society, edited by C. Gabay and K. Death, 129146. Oxford and New York: Routledge, 2014.

\footnotetext{
${ }^{1}$ Anjaria, “Ordinary States..."; Bayat, “Uncivil society..."; and Kamete, “Defending illicit livelihoods...".

${ }^{2}$ City of Johannesburg, Office of the Chief Operational Officer. Progress of the Inner City Informal Trading Task Team. Johannesburg: Report circulated to the main street traders organisations, 12 November 2013.

${ }^{3}$ Verbal commitment given in the participatory process started by the City of Johannesburg (Promulgation and Designation of Trading Spaces in the Inner City, August 2014) to "accommodate all legal traders".

${ }^{4}$ A declaration by the Member of the Mayoral Committee, Ruby Mathang, captured in the newspapers, and confirmed in a subsequent meeting by City officials (17.09.2014), mentioning the possible figure of 10000 legal trading spaces to be created in the inner city in the medium term.

${ }^{5}$ Bromley, "Street Vending and Public Policy: A Global Review"; Skinner, Street Trade in Africa: A Review.

${ }^{6}$ Kamete and Lindell, "The politics of 'non-planning'..."

${ }^{7}$ Skinner, Street Trade in Africa: A Review.

${ }^{8}$ See for instance, on the Indian case, Sinha and Roever, India's National Policy on Urban Street Vendors; Kumar, The Regularization of Street Vending in Bhubaneshwar, India: A Policy Model; and Grest, Statutory Representational Systems at Local Government Level: Ahmedabad, India.

${ }^{9}$ Dobson, and Skinner, Working in Warwick: Including Street traders in Urban Plans; and Horn, From Best Practice to Pariah...

${ }^{10}$ Ministry of Information, Cultural Affairs and Tourism (MICAT), Liberia. "Commerce Ministry, MCC, NAPETUL Sign MOU For Petty Traders", Official Liberian Government website, 3 November 2014, http://www.micatliberia.com/index.php/blog/item/473-commerce-ministry-mcc-napetul-sign-mou-for-pettytraders.html.

${ }^{11}$ It is less the case for secondary cities, where the pressure for sanitized inner city streets and the land use competition around inner city streetscape are often lower.

12 See Bénit-Gbaffou, "Operation Clean Sweep...".

${ }^{13}$ Morange, "Street trade, neoliberalisation and the control of space...".

${ }^{14}$ Kamete and Lindell, "The politics of 'non-planning'..."

${ }^{15}$ Bénit-Gbaffou, In quest of sustainable street trading management models...

${ }^{16}$ The Center for Urbanism and the Built Environment Studies, a research center based at Wits University.

${ }^{17}$ Bénit-Gbaffou (ed.), A political Landscape...

18 See for instance James V. "One Voice Hawkers' march purely opportunistic". Johannesburg News, 13 April 2011.

${ }^{19}$ Lindell, Africa's informal workers. Collective agencies and transnational organising in urban Africa

${ }^{20}$ Kamete, "Defending illicit livelihoods..."; and Wafer "Informality and the spaces of civil society...".

${ }^{21}$ Holston, Insurgent Citizenship...

22 Bayat, "Uncivil society...".

${ }^{23}$ Kamete, "Defending illicit livelihoods...".

${ }^{24}$ Anjaria, "Ordinary States..."; Simone, "People as Infrastructure...".

${ }^{25}$ Wafer "Informality and the spaces of civil society...".
} 


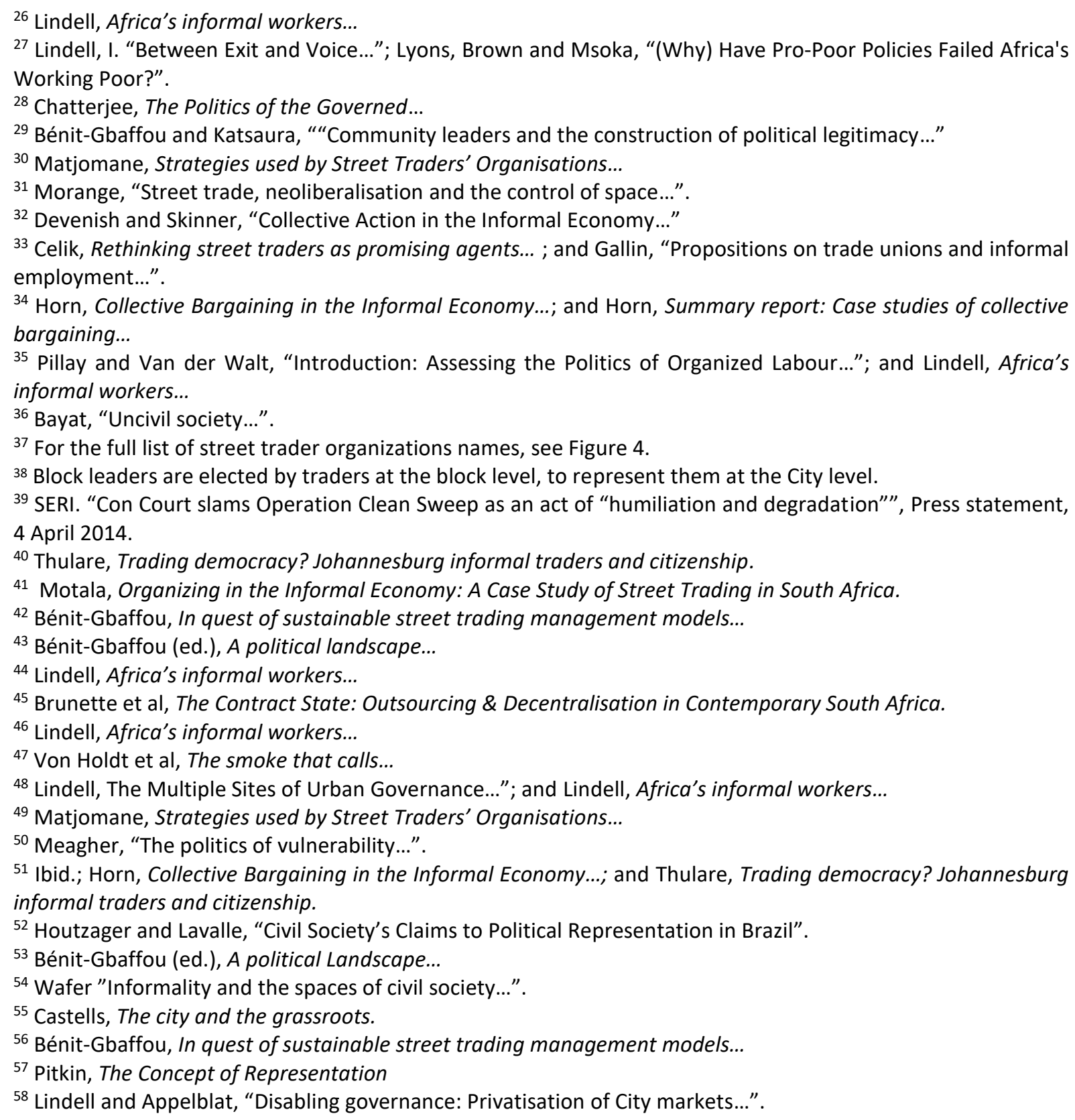

